\title{
SHARING ECONOMIC RENTS WITH INTERMEDIARIES: A STRATEGY FOR ESTABLISHING BRANDS AS RENT GENERATING ASSETS IN INTERNATIONAL MARKETS
}

\author{
Stephen C. Betts, William Paterson University, Wayne, New Jersey, USA
}

dx.doi.org/10.18374/JIBE-13-4.10

\begin{abstract}
As developing nations create new consumer bases, many companies are moved to expand their markets and introduce their brand names and branded products in these international arenas. In this paper we consider brands to be rent-generating assets. Customarily the owner of an asset collects the rents generated by that asset; however, in this paper we propose that in developing international markets there are situations where it is optimal for the owner of the brand to share rents with the distribution channel. The basic notion is that local intermediaries might be able to generate and increase the rent by taking actions that validate and enhance brand equity.
\end{abstract}

Keywords: Brand Equity, Economic Rents, International Marketing, Entry Strategies 